\title{
Probiotics in Asthma and Allergy Prevention
}

\author{
Maurizio Mennini', Lamia Dahdah', Maria Cristina Artesani', Alessandro Fiocchi ${ }^{1 *}$ and \\ Alberto Martelli ${ }^{2}$
}

${ }^{1}$ Division of Allergy, Bambino Gesù Children's Hospital, Vatican City, Vatican City, ${ }^{2}$ Department of Pediatrics, Salvini Hospital, Milan, Italy

Interest in probiotic research and its potential benefits in infant foods are relatively recent but significantly increasing. The evolution of the knowledge in the last 20 years demonstrated that alterations in the microbiome may be a consequence of events occurring during infancy or childhood, including prematurity, cesarean section, and nosocomial infections. Several pieces of evidence prove that a "healthy" intestinal microbiota facilitates the development of immune tolerance. Interventional studies suggest that probiotics could be protective against the development of many diseases. Nevertheless, many factors complicate the analysis of dysbiosis in subjects with food allergy. Comparison in-between studies are difficult, because of considerable heterogeneity in study design, sample size, age at fecal collection, methods of analysis of gut microbiome, and geographic location. Currently, there is no positive recommendation from scientific societies to use pre- or probiotics for treatment of food allergy or other allergic manifestations, while their use in prevention is being custom-cleared. However, the recommendation is still based on little evidence. Although there is valid scientific evidence in vitro, there is no sufficient information to suggest the use of specific probiotics in allergy and asthma prevention.

Keywords: probiotics, asthma, allergy, prevention, children

\section{INTRODUCTION}

The $2001 \mathrm{FAO} / \mathrm{WHO}$ definition of probiotics ("live microorganisms that, when administered in adequate amounts, confer a health benefit on the host") has been widely adopted by regulatory agencies, such as Codex alimentarius, the European Food Safety Authority (EFSA), scientists, industry, and consumers. Everyone agrees that a specific probiotic strain should have been investigated in properly controlled studies to confer a specific benefit before claiming the existence of such benefit. If this is not fulfilled, the only allowed claim would be "contains probiotics." Studies using probiotics or prebiotics have been generally designed as exploratory and were not sufficiently designed to fulfill the criteria for substantiation of a health claim under the current regulation by EFSA (1).

In order to recommend specific probiotics or a mixture of probiotic strains for allergy prevention, they must prove to reduce the risk of later allergies when given to the pregnant or breast-feeding mother or directly to the infant.

Interest in probiotic research and its potential benefits in infant foods is quite recent, but significantly increasing. According to a recent bibliometric analysis, the total number of documents published on probiotics in pediatrics over the period 1994-2014 was 2817. Research production 
on probiotics in pediatrics showed a 90 -fold increase during the study period. Approximately $22 \%$ of articles originated from USA and has the greatest share (2). The top 10 cited articles over the past two decades revealed that the majority of most important articles focused on the role of probiotics in the treatment of allergy and diarrhea in children. In Table 1, we summarize the main mechanisms of action of probiotics.

\section{PROBIOTICS IN PEDIATRICS}

In the last 20 years, it became clear that events occurring during infancy or childhood, including prematurity, cesarean section, and infections, influence the microbiome. Microbiome alterations have been associated with infantile colic, necrotizing enterocolitis, asthma, atopic diseases, diabetes, mood disorders, and autism spectrum disorders (3).

Interventional studies suggest that probiotics could prevent or reduce the severity of some of these diseases, but the biological mechanisms-and the optimal intervention for each-remain poorly understood.

\section{PROBIOTICS FOR ALLERGY PREVENTION}

A "healthy" intestinal microbiota facilitates the development of immune tolerance $(4,5)$. Earlier studies showed that gut-associated lymphoid tissues (GALT), including Peyer's patches, are poorly developed or absent in germ-free mice $(6,7)$. It was shown that the introduction of Bacteroides fragilis into the lower gut of germfree mice in the neonatal period could lead to a redevelopment of GALT and induction of tolerance (8). It was also proven that the inability to establish an effective immune tolerance early in life increases the host's risk of developing allergic and inflammatory diseases (9). For example, mice raised in a sterile environment show reduced immunoglobulin A and interleukin (IL)-10 producing $\mathrm{T}$ regulatory $\left(\mathrm{T}_{\text {reg }}\right)$ cells and are unable to develop oral antigenic tolerance $(7,10,11)$. Segmented filamentous bacteria and Clostridium species, particularly clusters IV and XIVa, promote the development of IL-17-producing $\mathrm{T}$ cells and $\mathrm{T}_{\text {reg }}$ cells, respectively $(12,13)$. Furthermore, the gut microbiota of food allergic mice-but not of tolerant ones - transmitted susceptibility to food allergy when transferred into germ-free mice (14).

Many factors complicate the analysis of dysbiosis in subjects with food allergy. Comparisons between studies are difficult,

TABLE 1 | Mechanisms of action of Probiotics.

\begin{tabular}{lcc}
\hline Microbiological action & Epithelial action & Immunological action \\
\hline - Modulation of the & - Modulation of the & - Innate immunity \\
composition of the & epithelial cell barrier & $\begin{array}{l}\text { modulation } \\
\text { microbiota }\end{array}$ \\
- Competitive adhesion to & - Expression of the tight & (maturation dendritic \\
the receptors with the & junction proteins & cells) \\
prevention of pathogens & - Short chain fatty acids & - Modulation of Th1/ \\
invasion & with improvement & Th2 rate \\
- Production & of epithelial barriers & Increase of number \\
of bacteriocin with & and anti-inflammatory & and activity of \\
prevention of growth & action & T regulatory cells \\
of pathogen & &
\end{tabular}

because of heterogeneity in study design, sample size, age at fecal collection, methods of analysis of gut microbiome, and geographic location (15). Nevertheless, evidence of gut dysbiosis in food allergy is evolving with time, aided by increasing availability of new techniques. Studies relying on bacterial cultures showed that infants allergic to cow's milk had higher total bacteria and anaerobic counts (16), but this finding was not consistent across studies (17) and no association could be established between culturable gut bacteria and sensitization to food, including milk, casein, egg, peanut, and hazelnut (18).

The hypothesized mechanisms by which the commensal microbiota influences the outcome of the allergic response are manifold (19). Intestinal bacteria can modulate the innate lymphoid cells, directly acting on $\mathrm{T}_{\text {regs }}$ through their toll-like receptors (TLRs). Commensal microbiota promotes the differentiation of induced $\mathrm{T}_{\text {regs }}\left(\mathrm{iT}_{\mathrm{reg}}\right.$ ) from naïve $\mathrm{CD} 4^{+} \mathrm{T}$-cells by a $\mathrm{T}_{\text {reg }}$ intrinsic, TLR- and myeloid differentiation primary response gene 88 (MyD88)-dependent mechanism $(20,21)$.

Another mechanism by which the commensal flora promotes tolerance is the production of short chain fatty acids (SCFAs), generated by bacterial fermentation of dietary fibers. SCFA act on T cells via a G-protein-coupled receptor (GPR43) and protect mice from intestinal inflammation by expanding colonic $\mathrm{T}_{\text {reg }}$ cells (22). SCFAs also promote the generation of intestinal $\mathrm{T}_{\text {reg }}$ cells from naïve $\mathrm{CD} 4^{+} \mathrm{T}$ cells by $\mathrm{T}$-cell intrinsic epigenetic mechanisms (23). Butyrate, a SCFA known as histone deacetylase inhibitor, increases Foxp3 protein acetylation conferring increased stability and enhanced suppressive function on de novo generated intestinal $\mathrm{iT}_{\text {reg }}$ cells (24). A high fiber diet protects against allergic airway inflammation by altering the composition of the flora, leading to increased Bacteroidetes and decreased Firmicutes, and resulting in increased circulating levels of SCFAs (25).

\section{PROBIOTICS FOR PREVENTION OF ASTHMA AND ECZEMA}

In general, preventive strategies for asthma and allergic disorders have been proposed in 2014 (26):

(1) General health education: avoidance of tobacco smoke exposure during pregnancy and after birth.

(2) Primary prevention for infants at higher risk. Several longitudinal birth cohort studies have clearly demonstrated an increased risk of allergic manifestations if one or two parents are or have been affected themselves.

(3) Secondary prevention strategies for children who have already developed allergic sensitization or the first manifestations of allergic diseases; those strategies aim to reduce the incidence of clinical manifestations, such as rhinitis, food allergy, or asthma.

Pre-clinical studies have shown that modifying the microbiota could modulate the global immune response of the host, thus reducing sensitization and allergic inflammation $(7,11)$. Many studies have suggested the hypothesis that pre- and probiotics might be protective for asthma. 
The inhalation of allergens stimulates the innate immune system to release cytokines which promote antigen expressions on $\mathrm{CD} 4^{+} \mathrm{T}$-cells and activate the antigen-presenting cells and the T cells to produce Th2 responses $(27,28)$. Th2 cytokines (IL-4, IL-5, IL-9, and IL-13) induce asthma-like changes in the airways and lung parenchyma, as airway eosinophilia, pulmonary lymphocytosis, mastocytosis, alternative macrophage activation, and epithelial cell proliferation with goblet cell hyperplasia. Previous studies have shown that matrix metalloproteinases, members of a family of enzymes that cleave extracellular matrix proteins, are implicated in many inflammatory conditions (29). Specifically, in asthma, MMP9 levels are significantly increased (30). Treatment with LGG has been shown to decrease MMP9 expression in lung tissue and to inhibit inflammatory cell infiltration. In addition, in OVA-sensitized mice, LGG reduced OVA-specific IgE levels in serum, suppressed the airway hyper-responsiveness to methacholine and decreased the number of infiltrating inflammatory cells and Th2 cytokines in bronchoalveolar lavage fluid and serum (31). Similar results have been reported with other probiotics (32).

Specifically, in pediatric asthma, LGG was reported to reduce the concentration of exhaled nitric oxide among 4- to 7-year-olds (33), but these results could not be replicated (34).

Early administration of Lactobacillus reuteri to infants did not result in a reduction of asthma [RR $1.16(0.33-4.10)]$, nor did Lactobacillus rhamnosus HN001 [RR 0.95 (0.62-145)] or Lactobacillus paracasei spp. paracasei F19 [RR 1.05 (0.39-2.81)] (35-37).

Better results have been obtained with probiotic bacteria based on in vitro modulation of cytokine production. Bifidobacterium bifidum, B. lactis, and Lc. lactis were shown to have a good IL-10-inducing capacity and to exert a significant inhibition of Th2-related cytokines IL-5 and IL-13 (38-40). Administered perinatally in a selected combination, they reduced the development of eczema up to the age of 2 years. Their beneficial effect does not reach the age of 6 years and does not lead to primary prevention of asthma.

A systematic review of randomized trials assessing the effects of any probiotic administered to pregnant women, breast-feeding mothers, or infants demonstrated that probiotics could reduce the risk of eczema in infants (41). The certainty in the evidence is low or very low because of the risk of bias, inconsistency and imprecision of results, and indirectness of available research.

As underlined in two recent reviews, replication of the promising results in collaborative well-coordinated multicentre harmonized studies with multidisciplinary expertise in pediatrics, immunology, and microbiology would, thus, be of great importance to enable future evidence-based implementation (42).

A more prolonged gut microbiota management could achieve a long-lasting impact $(43,44)$.

\section{GUIDELINES RECOMMENDATIONS: OVER TO SCIENTIFIC SOCIETIES}

- The European Academy of Allergy and Clinical Immunology (EAACI) stated in its food allergy and anaphylaxis guidelines on primary prevention of allergy, that "there is no evidence to recommend prebiotics or probiotics or other dietary supplements based on particular nutrients to prevent food allergy" in at risk groups and in the general population (grade of recommendation B) (45).

- The Nutrition Committee of the European Society of Paediatric Gastroenterology, Hepatology and Nutrition (ESPGHAN) concluded 2011 after a systematic literature review on the effect of infant formula supplemented with prebiotics or probiotics on the preventive effect on allergy, that "there is too much uncertainty to draw reliable conclusions from the available data" (46).

- The World Allergy Organization (WAO) suggested 2015 on their guidelines on the prevention of allergy to consider using probiotics in:

(a) women pregnant with children with high risk for allergy,

(b) women who breastfeed infants at high risk of developing allergy, and

(c) infants at risk of developing allergies, because there is a net benefit resulting in primary prevention of eczema (47).

\section{CONCLUSION}

There is no positive recommendation from any scientific community to use specific probiotics for the prevention of food allergy or other allergic manifestations (48), but their use in prevention as a whole class has widespread in clinical practice $(49,50)$. We are more open to the use of probiotics than in the past, but the recommendation is based on little evidence. Although there is valid scientific evidence in vitro, there is no sufficient information to suggest that the use of probiotics is effective in preventing allergy and asthma. At this point, it seems necessary to understand more precisely the microbiota composition of healthy humans. Only by identifying the specific changes, we would realize that the "ideal probiotic," able to prevent or fight specific dysbiosis of specific disease. Future studies will take stock of state-of-the-art methods for the evaluation of the microflora to better define the indications, the probiotic strains, and the type of prebiotic used.

\section{AUTHOR CONTRIBUTIONS}

MM, AF, and AM drafted the manuscript and provided critical input to the manuscript, and all authors approved the final version. LD and MA revised and approved the manuscript in this version. 


\section{REFERENCES}

1. van Loveren H, Sanz Y, Salminen S. Health claims in Europe: probiotics and prebiotics as case examples. Annu Rev Food Sci Technol (2012) 3:247-61. doi:10.1146/annurev-food-022811-101206

2. Sweileh WM, Shraim NY, Al-Jabi SW, Sawalha AF, Rahhal B, Khayyat RA, et al. Assessing worldwide research activity on probiotics in pediatrics using Scopus database: 1994-2014. World Allergy Organ J (2016) 25(9):25. doi:10.1186/s40413-016-0116-1

3. Fiocchi A, Burks W, Bahna SL, Bielory L, Boyle RJ, Cocco R, et al. Clinical use of probiotics in pediatric allergy (CUPPA): a world allergy organization position paper. World Allergy Organ J (2012) 5:148-67. doi:10.1097/ WOX.0b013e3182784ee 0

4. Hooper LV, Littman DR, Macpherson AJ. Interactions between the microbiota and the immune system. Science (2012) 336(6086):1268-73. doi:10.1126/ science. 1223490

5. Rudensky AY, Chervonsky AV. A narrow circle of mutual friends. Immunity (2011) 27(34):697-9. doi:10.1016/j.immuni.2011.05.008

6. Furrie E, Turner MW, Strobel S. Failure of SCID mice to generate an oral tolerance after a feed of ovalbumin: a role for a functioning gut-associated lymphoid system. Immunology (1994) 83(4):562-7.

7. Sudo N, Sawamura S, Tanaka K, Aiba Y, Kubo C, Koga Y. The requirement of intestinal bacterial flora for the development of an IgE production system fully susceptible to oral tolerance induction. J Immunol (1997) 15(159):1739-45.

8. Mazmanian SK, Liu CH, Tzianabos AO, Kasper DL. An immunomodulatory molecule of symbiotic bacteria directs maturation of the host immune system. Cell (2005) 15(122):107-18. doi:10.1016/j.cell.2005.05.007

9. McLoughlin RM, Mills KH. Influence of gastrointestinal commensal bacteria on the immune responses that mediate allergy and asthma. J Allergy Clin Immunol (2011) 127:1097-107; quiz 1108-9. doi:10.1016/j. jaci.2011.02.012

10. Fritz JH, Rojas OL, Simard N, McCarthy DD, Hapfelmeier S, Rubino S, et al. Acquisition of a multifunctional IgA+ plasma cell phenotype in the gut. Nature (2011) 11(481):199-203. doi:10.1038/nature10698

11. Geuking MB, Cahenzli J, Lawson MA, Ng DC, Slack E, Hapfelmeier S, et al. Intestinal bacterial colonization induces mutualistic regulatory $\mathrm{T}$ cell responses. Immunity (2011) 27(34):794-806. doi:10.1016/j.immuni.2011.03.021

12. Ivanov II, Atarashi K, Manel N, Brodie EL, Shima T, Karaoz U, et al. Induction of intestinal Th17 cells by segmented filamentous bacteria. Cell (2009) 30(139):485-98. doi:10.1016/j.cell.2009.09.033

13. Atarashi K, Tanoue T, Shima T, Imaoka A, Kuwahara T, Momose Y, et al. Induction of colonic regulatory $\mathrm{T}$ cells by indigenous Clostridium species. Science (2011) 21(331):337-41. doi:10.1126/science.1198469

14. Noval Rivas M, Burton OT, Wise P, Zhang YQ, Hobson SA, Garcia Lloret M, et al. A microbiota signature associated with experimental food allergy promotes allergic sensitization and anaphylaxis. J Allergy Clin Immunol (2013) 131:201-12. doi:10.1016/j.jaci.2012.10.026

15. Vernocchi P, Del Chierico F, Fiocchi AG, El Hachem M, Dallapiccola B, Rossi $\mathrm{P}$, et al. Understanding probiotics' role in allergic children: the clue of gut microbiota profiling. Curr Opin Allergy Clin Immunol (2015) 15:495-503. doi:10.1097/ACI.0000000000000203

16. Thompson-Chagoyan OC, Vieites JM, Maldonado J, Edwards C, Gil A. Changes in faecal microbiota of infants with cow's milk protein allergy - a Spanish prospective case-control 6-month follow-up study. Pediatr Allergy Immunol (2010) 21(2 Pt 2):e394-400. doi:10.1111/j.1399-3038.2009.00961.x

17. Adlerberth I, Strachan DP, Matricardi PM, Ahrné S, Orfei L, Aberg N, et al. Gut microbiota and development of atopic eczema in 3 European birth cohorts. J Allergy Clin Immunol (2007) 120:343-50. doi:10.1016/j.jaci.2007.05.018

18. Kendler M, Uter W, Rueffer A, Shimshoni R, Jecht E. Comparison of fecal microflora in children with atopic eczema/dermatitis syndrome according to IgE sensitization to food. Pediatr Allergy Immunol (2006) 17(2):141-7. doi:10.1111/j.1399-3038.2005.00371.x

19. Kabat AM, Srinivasan N, Maloy KJ. Modulation of immune development and function by intestinal microbiota. Trends Immunol (2014) 35:507-17. doi:10.1016/j.it.2014.07.010

20. Wang S, Charbonnier LM, Noval Rivas M, Georgiev P, Li N, Gerber G, et al. MyD88 adaptor-dependent microbial sensing by regulatory $\mathrm{T}$ cells promotes mucosal tolerance and enforces commensalism. Immunity (2015) 18(43):289-303. doi:10.1016/j.immuni.2015.06.014

21. Round JL, Lee SM, Li J, Tran G, Jabri B, Chatila TA, et al. The Toll-like receptor 2 pathway establishes colonization by a commensal of the human microbiota. Science (2011) 20(332):974-7. doi:10.1126/science.1206095

22. Smith PM, Howitt MR, Panikov N, Michaud M, Gallini CA, Bohlooly-Y M, et al. The microbial metabolites, short-chain fatty acids, regulate colonic Treg cell homeostasis. Science (2013) 2(341):569-73. doi:10.1126/science. 1241165

23. Furusawa Y, Obata Y, Fukuda S, Endo TA, Nakato G, Takahashi D, et al. Commensal microbe-derived butyrate induces the differentiation of colonic regulatory T cells. Nature (2013) 19(504):446-50. doi:10.1038/ nature 12721

24. Arpaia N, Campbell C, Fan X, Dikiy S, van der Veeken J, deRoos P, et al. Metabolites produced by commensal bacteria promote peripheral regulatory T-cell generation. Nature (2013) 19(504):451-5. doi:10.1038/nature12726

25. Trompette A, Gollwitzer ES, Yadava K, Sichelstiel AK, Sprenger N, NgomBru C, et al. Gut microbiota metabolism of dietary fiber influences allergic airway disease and hematopoiesis. Nat Med (2014) 20:159-66. doi:10.1038/ nm. 3444

26. Nieto A, Wahn U, Bufe A, Eigenmann P, Halken S, Hedlin G, et al. Allergy and asthma prevention 2014. Pediatr Allergy Immunol (2014) 25:516-33. doi:10.1111/pai.12272

27. Saenz SA, Taylor BC, Artis D. Welcome to the neighborhood: epithelial cellderived cytokines license innate and adaptive immune responses at mucosal sites. Immunol Rev (2008) 226:172-90. doi:10.1111/j.1600-065X.2008.00713.x

28. Otani IM, Anilkumar AA, Newbury RO, Bhagat M, Beppu LY, Dohil R, et al. Anti-IL-5 therapy reduces mast cell and IL-9 cell numbers in pediatric patients with eosinophilic esophagitis. J Allergy Clin Immunol (2013) 131:1576-82. doi:10.1016/j.jaci.2013.02.042

29. Keck T, Balcom JH IV, Fernández-del Castillo C, Antoniu BA, Warshaw AL. Matrix metalloproteinase-9 promotes neutrophil migration and alveolar capillary leakage in pancreatitis-associated lung injury in the rat. Gastroenterology (2002) 122:188-201. doi:10.1053/gast.2002.30348

30. Okada S, Kita H, George TJ, Gleich GJ, Leiferman KM. Migration of eosinophils through basement membrane components in vitro: role of matrix metalloproteinase-9. Am J Respir Cell Mol Biol (1997) 17:519-28. doi:10.1165/ ajrcmb.17.4.2877

31. Wu CT, Chen PJ, Lee YT, Ko JL, Lue KH. Effects of immunomodulatory supplementation with Lactobacillus rhamnosus on airway inflammation in a mouse asthma model. J Microbiol Immunol Infect (2016) 49:625-35. doi:10.1016/j.jmii.2014.08.001

32. Elazab N, Mendy A, Gasana J, Vieira ER, Quizon A, Forno E. Probiotic administration in early life, atopy, and asthma: a meta-analysis of clinical trials. Pediatrics (2013) 132:e666-76. doi:10.1542/peds.2013-0246

33. Kalliomäki M, Salminen S, Poussa T, Arvilommi H, Isolauri E. Probiotics and prevention of atopic disease: 4-year follow-up of a randomised placebo-controlled trial. Lancet (2003) 31(361):1869-71. doi:10.1016/ S0140-6736(03)13490-3

34. Kuitunen M, Kukkonen K, Juntunen-Backman K, Korpela R, Poussa T, Tuure T, et al. Probiotics prevent IgE-associated allergy until age 5 years in cesarean-delivered children but not in the total cohort. J Allergy Clin Immunol (2009) 123:335-41. doi:10.1016/j.jaci.2008.11.019

35. Abrahamsson TR, Jakobsson T, Björkstén B, Oldaeus G, Jenmalm MC. No effect of probiotics on respiratory allergies: a seven-year follow-up of a randomized controlled trial in infancy. Pediatr Allergy Immunol (2013) 24(6):556-61. doi:10.1111/pai.12104

36. Wickens K, Stanley TV, Mitchell EA, Barthow C, Fitzharris P, Purdie G, et al. Early supplementation with Lactobacillus rhamnosus HN001 reduces eczema prevalence to 6 years: does it also reduce atopic sensitization? Clin Exp Allergy (2013) 43:1048-57. doi:10.1111/cea.12154

37. West CE, Hammarström ML, Hernell O. Probiotics in primary prevention of allergic disease - follow-up at 8-9 years of age. Allergy (2013) 68(8):1015-20. doi:10.1111/all.12191

38. Gorissen DM, Rutten NB, Oostermeijer CM, Niers LE, Hoekstra MO, Rijkers GT, et al. Preventive effects of selected probiotic strains on the development of asthma and allergic rhinitis in childhood. The Panda study. Clin Exp Allergy (2014) 44(11):1431-3. doi:10.1111/cea.12413 
39. Niers LE, Timmerman HM, Rijkers GT, van Bleek GM, van Uden NO, Knol EF, et al. Identification of strong interleukin-10 inducing lactic acid bacteria which down-regulate $\mathrm{T}$ helper type 2 cytokines. Clin Exp Allergy (2005) 35:1481-9. doi:10.1111/j.1365-2222.2005.02375.x

40. Niers LE, Hoekstra MO, Timmerman HM, van Uden NO, de Graaf PM, Smits $\mathrm{HH}$, et al. Selection of probiotic bacteria for prevention of allergic diseases: immunomodulation of neonatal dendritic cells. Clin Exp Immunol (2007) 149:344-52. doi:10.1111/j.1365-2249.2007.03421.x

41. Forsberg A, West CE, Prescott SL, Jenmalm MC. Pre- and probiotics for allergy prevention: time to revisit recommendations? Clin Exp Allergy (2016) 46:1506-21. doi:10.1111/cea.12838

42. West CE, Jenmalm MC, Kozyrskyj AL, Prescott SL. Probiotics for treatment and primary prevention of allergic diseases and asthma: looking back and moving forward. Expert Rev Clin Immunol (2016) 12:625-39. doi:10.1586/1 744666X.2016.1147955

43. Cuello-Garcia CA, Brożek JL, Fiocchi A, Pawankar R, Yepes-Nuñez JJ, Terracciano L, et al. Probiotics for the prevention of allergy: a systematic review and meta-analysis of randomized controlled trials. J Allergy Clin Immunol (2015) 136(4):952-61. doi:10.1016/j.jaci.2015.04.031

44. Yatsunenko T, Rey FE, Manary MJ, Trehan I, Dominguez-Bello MG, Contreras $\mathrm{M}$, et al. Human gut microbiome viewed across age and geography. Nature (2012) 9(486):222-7. doi:10.1038/nature11053

45. Muraro A, Halken S, Arshad SH, Beyer K, Dubois AE, Du Toit G, et al. EAACI Food Allergy and Anaphylaxis Guidelines Group. EAACI food allergy and anaphylaxis guidelines. Primary prevention of food allergy. Allergy (2014) 69(8):1046-57. doi:10.1111/all.12441

46. Braegger C, Chmielewska A, Decsi T, Kolacek S, Mihatsch W, Moreno L, et al. ESPGHAN Committee on Nutrition. Supplementation of infant formula with probiotics and/or prebiotics: a systematic review and comment by the ESPGHAN committee on nutrition. J Pediatr Gastroenterol Nutr (2011) 52(2):238-50. doi:10.1097/MPG.0b013e3181fb9e80
47. Fiocchi A, Pawankar R, Cuello-Garcia C, Ahn K, Al-Hammadi S, Agarwal A, et al. World Allergy Organization-McMaster University Guidelines for allergic disease prevention (GLAD-P): probiotics. World Allergy Organ J (2015) 8(1):4. doi:10.1186/s40413-015-0055-2

48. Szajewska H, Shamir R, Turck D, van Goudoever JB, Mihatsch WA, Fewtrell M. Recommendations on probiotics in allergy prevention should not be based on pooling data from different strains. J Allergy Clin Immunol (2015) 136(5):1422. doi:10.1016/j.jaci.2015.07.022

49. Cuello-Garcia CA, Brożek JL, Fiocchi A, Pawankar R, Yepes-Nuñez JJ, Terracciano L, et al. Reply: to PMID 26044853. J Allergy Clin Immunol (2015) 136(5):1423-5. doi:10.1016/j.jaci.2015.07.021

50. Fiocchi A, Fierro V, La Marra F, Dahdah LA. The custom clearance of proand prebiotics in allergy prevention. Ann Allergy Asthma Immunol (2016) 117(5):465-7. doi:10.1016/j.anai.2016.05.008

Conflict of Interest Statement: The authors declare that the research was performed in the absence of any commercial or financial relationships that could be construed as a potential conflict of interest.

The reviewer, CM, and handling editor declared their shared affiliation, and the handling editor states that the process nevertheless met the standards of a fair and objective review.

Copyright (c) 2017 Mennini, Dahdah, Artesani, Fiocchi and Martelli. This is an open-access article distributed under the terms of the Creative Commons Attribution License (CC BY). The use, distribution or reproduction in other forums is permitted, provided the original author(s) or licensor are credited and that the original publication in this journal is cited, in accordance with accepted academic practice. No use, distribution or reproduction is permitted which does not comply with these terms. 